\title{
Reclassification of Pediococcus urinaeequi (ex Mees 1934) Garvie 1988 as Aerococcus urinaeequi comb. nov.
}

\author{
Giovanna E. Felis, Sandra Torriani and Franco Dellaglio \\ Dipartimento Scientifico e Tecnologico, Università degli Studi di Verona, Strada le Grazie 15, \\ 37134 Verona, Italy
}

Correspondence

Franco Dellaglio

franco.dellaglio@univr.it

\begin{abstract}
The taxonomic status of Pediococcus urinaeequi is described, and the transfer of the species to the genus Aerococcus with the name Aerococcus urinaeequi comb. nov. is proposed, on the basis of the analysis of 16S rRNA gene sequence and DNA-DNA hybridization data.
\end{abstract}

The formal description of the species Pediococcus urinaeequi was formulated by E. I. Garvie in 1986, and the name was validated in the Approved List of Bacterial Names (Garvie, 1988). The species consists of alkaline-tolerant, tetradforming cocci. Pediococci are lactic acid bacteria, characterized by spherical cells that divide alternately in two planes at right angles to form tetrads. They are chemoorganotrophs, requiring a rich medium for growth. Gas is not formed from fermentation of carbohydrates, which usually leads to the formation of DL- or L-lactate. Garvie (1986) suggested that the separation of the genus Pediococcus from the genus Aerococcus required further clarification, with particular reference to the taxonomic position of $P$. urinaeequi, on the basis of the following observations. High DNA-DNA hybridization values were shared by strains of $P$. urinaeequi and Aerococcus viridans (Dellaglio et al., 1974), no DNA-DNA relatedness between some $P$. urinaeequi strains and either Pediococcus halophilus (now Tetragenococcus halophilus) or other A. viridans strains was found by Dellaglio et al. (1981) and, finally, strains of $P$. urinaeequi and $A$. viridans showed the same cross-linkage in their cell wall peptidoglycan (L-Lys-L-Ala), which was different from that of other pediococci (L-LysL-Ala-D-Asp).

A subsequent phylogenetic analysis performed on $16 \mathrm{~S}$ rRNA gene sequences by Collins et al. (1990) confirmed that the type strain of $P$. urinaeequi was more similar to strains of the genus Aerococcus, and to the species A. viridans in particular, than to other Pediococcus species. Based on this result, Simpson \& Taguchi (1995) and Stiles \& Holzapfel (1997) reported that the species $P$. urinaeequi did not belong to the genus Pediococcus.

Published online ahead of print on 14 January 2005 as DOI 10.1099/ ijs.0.63324-0.

The GenBank/EMBL/DDBJ accession number for the 16s rRNA gene sequence of Pediococcus claussenii DSM $14800^{\top}$ is AJ621555.
No formal reclassification has ever been proposed; therefore $P$. urinaeequi is still a species with a validly published name belonging to the genus Pediococcus. The aim of the present study was the reinvestigation and clarification of its taxonomic position.

Small subunit (16S) rRNA gene sequences of $P$. urinaeequi and other bacterial species were obtained from GenBank; sequence accession numbers and strain numbers are given in Fig. 1. The $16 \mathrm{~S}$ rRNA gene sequence for Pediococcus claussenii DSM $14800^{\mathrm{T}}$ was obtained using primers Lac16S-f (5'-AAT GAG AGT TTG ATC CTG GCT-3') and Lac16S-r (5'-GAG GTG ATC CAG CCG CAG GTT-3'). The reaction mixture $(20 \mu \mathrm{l})$ contained $30 \mathrm{ng}$ template DNA, $1.5 \mathrm{mM}$ $\mathrm{MgCl}_{2}, 0 \cdot 2 \mathrm{mM}$ dNTPs, $1 \mu \mathrm{M}$ of each primer and $1 \mathrm{U}$ Taq DNA polymerase (Polymed), in a standard reaction buffer. After an initial denaturation of $4 \mathrm{~min}$ at $94^{\circ} \mathrm{C}, 25$ cycles of $1 \mathrm{~min}$ at $94^{\circ} \mathrm{C}, 1.5 \mathrm{~min}$ at $50^{\circ} \mathrm{C}, 2 \mathrm{~min}$ at $72{ }^{\circ} \mathrm{C}$ and final extension at $72{ }^{\circ} \mathrm{C}$ for 7 min were performed. The $1.6 \mathrm{~kb}$ amplification products were extracted from an agarose gel (Promega elution kit) and sequenced at the Biomolecular Research (BMR) Center at Padua University (Italy).

Using the same procedure, the 16S rRNA gene sequence of $P$. urinaeequi $\mathrm{LMG} 13989^{\mathrm{T}}$ was obtained. It was almost identical to that deposited in GenBank/EMBL/DDBJ for P. urinaeequi IFO 12173 (accession no. D87677).

Sequences were aligned with the CLUSTAL_X program (Thompson et al., 1997). Positions ambiguously aligned, not available or not identified ( $\mathrm{N}$ in the sequence) were removed from all the sequences. Several phylogenetic trees were obtained with various distance formulas (Kimura, Tajima-Nei, Tamura three-parameter) and neighbourjoining reconstruction, as implemented in MEGA version 2.1 (Kumar et al., 2001), and with the Galtier-Gouy model as implemented in TREECON (Van de Peer \& De Wachter, 1994). Parsimony analysis was performed as implemented in MEGA version 2.1 (Kumar et al., 2001), and a maximumlikelihood phylogenetic reconstruction was also obtained 


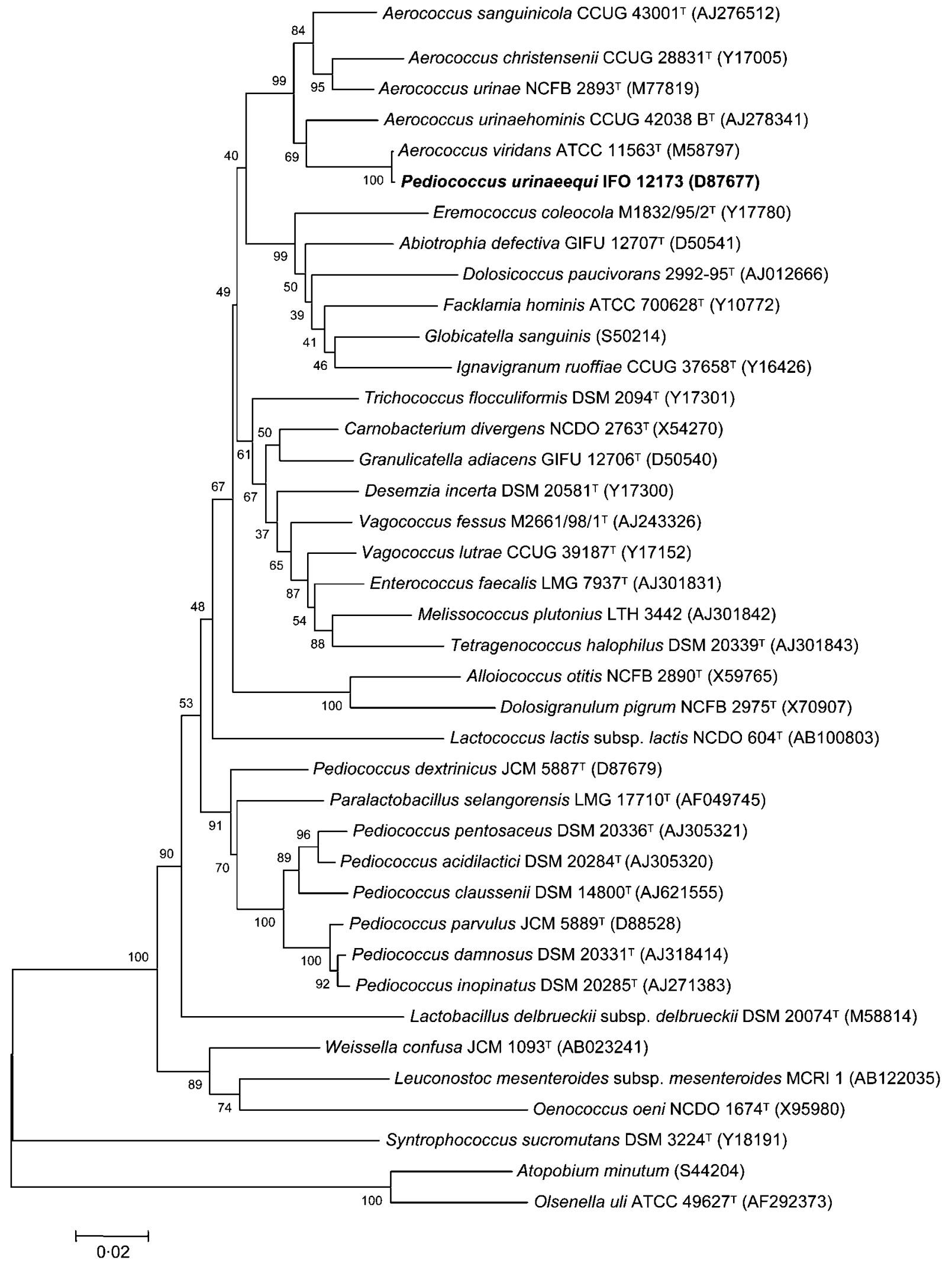

Fig. 1. Phylogenetic tree based on $16 \mathrm{~S}$ rRNA gene sequences, inferred using the Tamura three-parameter distance and neighbour-joining tree reconstruction. Bar, number of nucleotide substitutions per site. 
with models HKY and SH as implemented in TREE-PUZZLE (Strimmer \& von Haeseler, 1996). The results obtained were very similar in all cases. An example is given in Fig. 1.

The close relationship of $P$. urinaeequi IFO 12173 and $A$. viridans ATCC $11563^{\mathrm{T}}$ is evident, and is due to a similarity value of $99 \cdot 9 \%$ (1407 identical nucleotides out of 1409 unambiguously aligned and not degenerated available positions) between the two sequences. This low divergence may indicate that the two species form the same taxon. Since $16 \mathrm{~S}$ rRNA gene identity may not be sufficient to guarantee species identity (Fox et al., 1992), a DNA-DNA hybridization test was performed at the DSMZ: a 50.9\% (replicate $51 \cdot 3 \%$ ) total DNA-DNA similarity between $P$. urinaeequi LMG $13989^{\mathrm{T}}$ and A. viridans DSM $20340^{\mathrm{T}}$ was found, indicating that the two strains belong to separate species.

On the basis of these results it is proposed that the species $P$. urinaeequi be reclassified as a novel species within the genus Aerococcus, with the name Aerococcus urinaeequi comb. nov. (Rule 4la of the Bacteriological Code; Lapage et al., 1992).

The genus Aerococcus is therefore constituted of six species instead of five. For an easier consultation of data concerning the species A. urinaeequi, the description of the reclassified species P. urinaeequi from Garvie (1986) is reported.

\section{Description of Aerococcus urinaeequi comb. nov.}

Basonym: Pediococcus urinaeequi (ex Mees 1934) Garvie 1988.

Aerococcus urinaeequi (u.rin'ae.e.qui. n. L. urina -ae urine; L. n. gen. equus $-i$ horse; gen. equi of a horse; urinaeequi from the urine of a horse, source of isolation of the strain).

Cells are spherical, never elongated. Division occurs alternately in two planes at right angles to form tetrads. Gram-positive, non-motile, non-spore-forming, facultative anaerobes. Cells might form irregular clusters when grown in liquid medium. Catalase-negative. According to previous descriptions, the optimum $\mathrm{pH}$ value for growth is between 8.5 and $9 \cdot 0$, with growth commencing in medium at an initial $\mathrm{pH}$ of $6 \cdot 5$ to $7 \cdot 0$ (Simpson \& Taguchi, 1995). Grows well in Trypticase Soy broth containing yeast extract $(0.3 \%$, $\mathrm{w} / \mathrm{v}$ ), at a final $\mathrm{pH}$ of $7 \cdot 2 \pm 0 \cdot 2$. Optimum temperature is $25-30{ }^{\circ} \mathrm{C}$. ( +)-L-Lactate is formed from glucose. Acid is produced from maltose, sucrose, trehalose and dextrin, but not from melezitose, starch, glycerol or sorbitol. Straindependent reactions are obtained with arabinose, xylose, lactose and mannitol. $\mathrm{G}+\mathrm{C}$ content of the DNA is $39 \cdot 5 \mathrm{~mol} \%$.
The type strain is ATCC $29723^{\mathrm{T}}$ [= CCUG $28094^{\mathrm{T}}=$ CIP $103442^{\mathrm{T}}=$ LMG $13989^{\mathrm{T}}=$ DSM $20341^{\mathrm{T}}=$ NCIMB $701636^{\mathrm{T}}$ (formerly NCDO $1636^{\mathrm{T}}$ )].

\section{References}

Collins, M. D., Williams, A. M. \& Wallbanks, S. (1990). The phylogeny of Aerococcus and Pediococcus as determined by $16 \mathrm{~S}$ rRNA sequence analysis: description of Tetragenococcus gen. nov. FEMS Microbiol Lett 58, 255-262.

Dellaglio, F., Bottazzi, V. \& Battistotti, B. (1974). Caratteri e distribuzione della microflora pediococcica in alcuni formaggi italiani. Ann Microbiol Enzimol 24, 325-334.

Dellaglio, F., Trovatelli, L. D. \& Sarra, P. G. (1981). DNA-DNA homology among representative strains of the genus Pediococcus. Zentralbl Bakteriol Mikrobiol Hyg 1 Abt Orig C 2, 140-150.

Fox, G. E., Wisotzkey, J. D. \& Jurtshuk, P., Jr (1992). How close is close: $16 \mathrm{~S}$ rRNA sequence identity may not be sufficient to guarantee species identity. Int J Syst Bacteriol 42, 166-170.

Garvie, E. I. (1986). Genus Pediococcus Claussen 1903, $68^{\mathrm{AL}}$. In Bergey's Manual of Systematic Bacteriology, vol. 2, pp. 1075-1079. Edited by P. H. A. Sneath, N. S. Mair, M. E. Sharpe \& J. G. Holt. Baltimore: Williams \& Wilkins.

Garvie, E. I. (1988). Pediococcus urinaeequi nom. rev. In Validation of the Publication of New Names and Combinations Previously Effectively Published Outside the IJSB, List no. 25. Int J Syst Bacteriol 38, 220-222.

Kumar, S., Tamura, K., Jakobsen, I. B. \& Nei, M. (2001). MEGA2: molecular evolutionary genetics analysis software. Bioinformatics 17, 1244-1245.

Lapage, S. P., Sneath, P. H. A., Lessel, E. F., Skerman, V. B. D., Seeliger, H. P. R. \& Clark, W. A. (editors) (1992). International Code of Nomenclature of Bacteria (1990 Revision). Bacteriological Code. Washington, DC: American Society for Microbiology.

Simpson, W. J. \& Taguchi, H. (1995). The genus Pediococcus, with notes on the genera Tetragenococcus and Aerococcus. In The Lactic Acid Bacteria, vol. 2, The Genera of Lactic Acid Bacteria, pp. 125-172. Edited by B. J. B. Wood \& W. H. Holzapfel. London: Blackie Academic \& Professional.

Stiles, M. E. \& Holzapfel, W. H. (1997). Lactic acid bacteria of food and their current taxonomy. Int J Food Microbiol 36, 1-29.

Strimmer, K. \& von Haeseler, A. (1996). Quartet puzzling: a quartet maximum likelihood method for reconstructing tree topologies. Mol Biol Evol 13, 964-969.

Thompson, J. D., Gibson, T. J., Plewniak, F., Jeanmougin, F. \& Higgins, D. G. (1997). The CLUSTAL_X Windows interface: flexible strategies for multiple sequence alignment aided by quality analysis tools. Nucleic Acids Res 24, 4876-4882.

Van de Peer, Y. \& De Wachter, R. (1994). TREECON for Windows: a software package for the construction and drawing of evolutionary trees for the Microsoft Windows environment. Comput Appl Biosci 10, 569-570. 